\title{
The emergence of the modern environmental movements, 1959-1972
}

On Sunday 16 March 1969, Nature and Youth Sweden Fältbiologerna [literally The Field Biologists] in Swedish - held a nationwide demonstration against the expansion of hydroelectric power in northern Sweden. The biggest gathering took place in central Stockholm, where a couple of hundred people met in order to march from Östermalmstorg to Sergels Torg, a distance of approximately 800 metres. Svenska Dagbladet described it as a demonstration 'of a somewhat unusual kind', and Dagens Nyheter pointed out that the young people did not look like 'ordinary demonstrators'. 'Their placards bore messages such as 'Killing nature is suicide', 'Welfare is a pristine river', and 'Your children are protesting against your short-sightedness'. ${ }^{2}$ From the rostrum at Sergels Torg, Nature and Youth Sweden's chairman, Wolter Arnberg, sharply criticized the short-term economic interests which 'always and without exception' caused environmental interests to be crushed. He demanded that the plans to exploit the Vindel, Kaitum, and upper Lule Rivers be mothballed immediately 'so that the nuclear power plants can demonstrate that there are concrete alternatives to hydroelectric power'. ${ }^{3}$

The notion that nuclear power was environmentally friendly was well established in late 1960s Sweden. Ever since the 1950s, nature-conservation bodies had hoped that the new technology would put a stop to the continued exploitation of the great rivers

1 Anon., 'Kamp för Kaitum på Östermalmstorg', DN, 17 March 1969; Monica Anrep-Nordin, 'De vill rädda vår vildmark', SvD, 17 March 1969.

2 Anon., 'Kamp för Kaitum på Östermalmstorg'; Anrep-Nordin, 'De vill rädda vår vildmark'.

3 Anon., 'Tal framfört på Sergels Torg den 16.31969 vid Fältbiologernas demonstration mot vattenkraftutbyggnaden i fjällen', Fältbiologen (FB), 3 (1969), pp. 4-5. 
of the north. By preserving untouched wilderness from the advance of civilization, these interest groups wanted to secure aesthetic natural values and opportunities for recreation and outdoor life. ${ }^{4}$ The protest against the expansion of hydroelectric power on 16 March received a good deal of attention in the press and broadcast media, which claimed that Nature and Youth Sweden was not an organization that is usually 'associated with demonstration marches'. That situation was about to change, though. In the years around 1970, Nature and Youth Sweden's focus and activities were recast. Whereas the young people had previously devoted themselves to birdwatching, nature studies, and camping activities, they became increasingly known for direct actions and far-reaching social criticism. ${ }^{6}$ Consequently, the association became a visible and influential part of the emerging Swedish environmental movement. In parallel with this shift, its membership grew rapidly, from about 3,000 in the mid-1960s to over 10,000 in the early 1970 s. $^{7}$

The history of Nature and Youth Sweden dates back to 1947. At that time, Sveriges Fältbiologiska Ungdomsförening (SFU) was formed as a youth branch of the Swedish Society for Nature Conservation (SNF), which was the oldest and largest natureconservation organization in the country. SNF's original ambition was to become a popular movement, but up until 1955 it never had more than 5,000 members. It was an expert organization dominated by a scientific elite and with close ties to the state and to the university world. In the 1960s, however, its membership base expanded, and by 1970 SNF had about 50,000 members. ${ }^{8}$ By contrast, Nature and Youth Sweden was an independent association run by the young members themselves. It was open to everyone aged 7 to 25 years. Its aim was to spread and increase knowledge about nature among children and young people. The fundamental

4 Jonas Anshelm, Mellan frälsning och domedag: Om kärnkraftens politiska idéhistoria i Sverige 1945-1999 (Eslöv: Symposion, 2000), pp. 100-102; Anshelm, Det vilda, det vackra och det ekologiskt hällbara, p. 32.

5 Anon., 'Kamp för Kaitum på Östermalmstorg'.

6 This chapter is based on Anna Kaijser and David Larsson Heidenblad, 'Young Activists in Muddy Boots: Fältbiologerna and the Ecological Turn in Sweden, 1959-1974', Scandinavian Journal of History 43.3 (2018).

7 Helena Klöfver, Håll stövlarna leriga och för bofinkens talan: Naturintresse, miljömedvetenhet och livsstil inom organisationen Fältbiologerna (Linköping: Tema V report, 1992), pp. 36-37.

8 Anshelm, Det vilda, det vackra och det ekologiskt hållbara, p. 8. 
idea was that this was best done directly in the field and through peer education. ${ }^{9}$

Nature and Youth Sweden's activities were organized in the form of local clubs, which numbered about a hundred by the mid-1960s. Recruitment mainly happened through schools, where active members of the association spread the word about their activities. The clubs arranged excursions and meetings. Many local clubs published their own mimeographed membership magazines. The association's most important communication channel was the printed magazine Fältbiologen [The field biologist]. It was sent to all members six times a year. Through the magazine, it is possible to study Nature and Youth Sweden's ideological development and gain insights into its activities. From having been an apolitical association for natureinterested youth, Nature and Youth Sweden became a breeding ground and base for environmental activism. When and how did this change occur? What did it actually consist of? And what role did Nature and Youth Sweden play in and for the emergence of organized environmental movements in Sweden? To investigate these matters, I will begin by looking back at the state of Nature and Youth Sweden before the environmental issues had their big breakthrough.

\section{Nature-interested young people, 1959-1966}

In 1959, Nature and Youth Sweden's parent organization, the Swedish Society for Nature Conservation, celebrated its fiftieth anniversary. This prompted Lars-Erik Åse, a member of Nature and Youth Sweden, to reflect on the passage of history. He asserted that no other fifty-year period had been 'so rich in transformations and upheavals'. Sweden had developed into one of the world's richest countries. The prosperity and standard of living of the late 1950s could not have been dreamed of by the 'Swedish inhabitants of the turn of the century'. These rapid developments were gratifying in many ways; Swedes had gained 'better housing, better food, cars,

9 Thomas Söderqvist, The Ecologists: From Merry Naturalists to Saviours of the Nation: A Sociologically Informed Narrative Survey of the Ecologization of Sweden 1895-1975 (Stockholm: Almqvist \& Wiksell International, 1986); Jamison, Eyerman, and Cramer, The Making of the New Environmental Consciousness, pp. 18, 31; Klöfver, Håll stövlarna leriga; Helena Klöfver, Miljömedvetenhet och livsstil bland organiserade ungdomar (Linköping: Linköpings universitet, 1995); Wennerholm, Framtidsskaparna, pp. 248-278. 
televisions, and more leisure time'. However, Åse was concerned that humanity had not kept up with this progress. Human beings did not seem to be able to keep pace with the advances of technology. Manifestations of this discrepancy included the increasing incidence of 'neuroses and nerve diseases' and the growth of juvenile delinquency.

Åse's overall explanation was that 'the modern human' had lost contact with nature and lacked 'interest in and feeling for nature'. This loss made Nature and Youth Sweden's activities important, because that was precisely what the association was trying to give its members. It did so 'not by preaching and admonishing', but by cultivating individual members' fascination with the interaction between plants and animals. From there, Åse argued, it was a straight line to nature conservation; because people who had an 'interest in and feeling for nature' would automatically wish 'to protect and preserve endangered areas'. This desire could frequently lead to conflicts with industrial and economic interests. Ase concluded: 'Here the question becomes whether we might consider sacrificing some small part of our high standard of living' in order to preserve beautiful and atmospheric landscapes. ${ }^{10}$

The views expressed by Lars-Erik Åse in 1959 were typical of the older nature-conservation tradition within which Nature and Youth Sweden had been formed. The tradition was strongly coloured by Romanticism, which emphasized feelings and experiences of wild nature. Untouched nature was said to possess aesthetic, almost spiritual, values which modern cultural landscapes were thought to lack. Great emphasis was also placed on the scientific study of nature. Special topics such as ornithology, botany, entomology, and ecology were highly valued. For Nature and Youth Sweden, knowledge about nature and feelings for it were two sides of the same coin.

So why was it so important to protect wild nature? Karin Furuwidh, chair of Nature and Youth Sweden in 1960, was clear about the answer. 'Remember', she wrote, 'that a plentiful and untouched nature is the very foundation for our hobbies!"11 This recreational leisure argument was repeatedly made in Fältbiologen's columns during the early 1960s. Wild nature should be saved from the advance of modern civilization so that humans, not least young nature enthusiasts, could continue to enjoy it. This theme was often

10 Lars-Erik Åse, 'Fältbiologi och naturvård', FB, 5 (1959), p. 2.

11 Karin Furuwidh, 'SFU:aren och Naturvården', FB, 1 (1960), p. 3. 
combined with historical references to rising prosperity, increasing leisure, and the emergence of motoring. ${ }^{12}$ Anne von Hofsten stressed that these developments were placing ever-higher demands on nature, and that humanity's responsibility had increased as a result. She maintained that 'it is we who must train ourselves and other young people to interact with nature in the right way', because within a few years it is 'our generation' that will lead the country. ${ }^{13}$

Members of Nature and Youth Sweden were not outspoken critics of technology and civilization. For example, Clas Bergman argued that it was a good thing that 'more people have been able to acquire a car', because it gave them 'increased opportunities to get out into nature'. The problem was that many car owners behaved dishonourably by unscrewing the licence plates and dumping old cars in the countryside. There they could stand 'in all their hideousness almost forever'. Bergman described this fly-tipping problem as destroying nature, which in this context meant that nature's aesthetic qualities were being nullified. There was no belief that the car wrecks constituted any direct danger to plant and animal life, much less to humans. ${ }^{14}$

However, in an article that appeared a year later, in 1961, the same Clas Bergman asserted that humans' economic encroachments into nature risked causing greater and more profound damage. He highlighted 'the ever-increasing use of toxins in the forestry and agricultural industries'. The problems were still insufficiently investigated, he said, but alarming US studies indicated that bird populations and breeding successes had fallen sharply in the wake of increased toxin use. Bergman emphasized that nature enthusiasts must become more vigilant. The use of toxins involved large sums of money, and its socioeconomic significance was rapidly increasing. ${ }^{15}$ Another growing problem was oil spills. Fältbiologen reported that the newspapers and television had recently been full of reports about the 'terrible effects of oil damage on certain bird species'. ${ }^{16}$

During the early 1960s, Nature and Youth Sweden's interest in and commitment to nature conservation were significant. However, the association's activities were primarily aimed at helping its members

12 Per-Erik Tonell, 'Naturen samhället och vi', FB, 4 (1962), pp. 2-3; Roger Gyllin, 'Några synpunkter på naturvård - två inlägg', FB, 3 (1963), pp. 22-24.

13 Anne von Hofsten, 'Annes syn på saken', FB, 2 (1961), p. 2.

14 Clas Bergman, 'Höstfunderingar', FB, 3 (1960), p. 2.

15 Clas Bergman, 'Varför djurskydd?', FB, 3 (1961), p. 4.

16 Bredo von Bornstedt, 'Om oljeskadorna', FB, 2 (1962), p. 6. 
to experience and learn more about nature. For that reason, these activities chiefly involved hiking, camping, and excursions. Fältbiologen published recurring reports from these events. It was with one such report, from 1964, that one member of the association, Erik Isakson, made his debut as a writer. The preamble described him as 'one of the Stockholm club's great fighters' and announced that he was going to 'lead the Stockholm district's toughest camp' during the summer. This was a tent camp in northernmost Sweden, with planned challenging hiking trips to Finland, Norway, and the Russian border. In a letter to the editors Isakson said that, as early as the beginning of May, he had gone north to 'leave the noise behind' and study the arrival of birds in mountains and wetlands. The letter described the species of birds he had seen and heard in detail. $^{17}$

The next issue included a long report from the summer camp. Isakson described how twelve young members of Nature and Youth Sweden had travelled from Stockholm on 10 June and not returned home until 11 July. All the campers were boys in their late teens. A photograph in the magazine showed them posing for the camera carrying heavy backpacks. Isakson stressed the many difficulties they had overcome together: hunger, cold, and severe weather. One of the participants had fallen on sharp rocks and spat out 'teeth and blood'. On another occasion they had encountered Finnish soldiers with machine guns, who had taken them 'the shortest way back to civilization'. The adventure-filled stories were combined with detailed descriptions of nature and birdlife. The article was a playful display of interest and knowledge presented in a light, humorous way. Isakson said that the young adventurers always slept for a long time, because otherwise they would not have 'had the strength to see all these birds'. ${ }^{18}$

Erik Isakson was hardly a typical member of Nature and Youth Sweden. The vast majority of its members did not go to month-long summer camps in the wilderness. However, Isakson appeared regularly in Fältbiologen's columns from 1964 onwards. Belonging to the inner circle of the Stockholm club, he had close contacts with the editorial staff. Consequently, he became visible to members in the rest of Sweden as well. Through his descriptions of nature and travel, he manifested many of the association's highest ideals:

17 Erik Isakson, 'Lappländsk vårvinter', FB, 3 (1964), pp. 13-15.

18 Erik Isakson, 'Nordkallet runt', FB, 4 (1964), pp. 10-15. 
a desire for adventure, an interest in nature and the wilderness, activity and commitment, plus deep special knowledge about animal and birdlife.

As the 1960s progressed, the association combined its interest in experiencing and studying nature with increasingly diligent nature-conservation efforts. ${ }^{19}$ In the wake of Rachel Carson's Silent Spring and the Swedish biocide debate, the association launched a campaign called 'Samla kalla fakta' [Collect Hard Facts]. It amounted to sending dead animals to the National Veterinary Institute for autopsy. The members' aim was to help researchers obtain scientific evidence for the harmful effects of biocides. Individual members were encouraged to provide real assistance 'by submitting all the dead things you find in nature'. ${ }^{20}$ The campaign ran for two years (1963-1965) and marked the beginning of a phase of more direct commitment to nature-conservation issues. ${ }^{21}$

On Sunday 27 March 1966, another significant direct action occurred: the 'Clean a beach' event on the west coast of Skåne in southernmost Sweden. It was initiated by the Skåne district's submanagement working committee and a number of local clubs. They had been inspired by the Swedish Society for Nature Conservation's national campaign against littering in nature, Hall Sverige Rent [Keep Sweden Clean], which had been run several times in the course of the 1960s. The Nature and Youth Sweden action was supported by local landowners who provided tractors, trailers, and trucks. The regional Håll Skane Rent campaign supplied paper bags to hold the rubbish.

Prior to the action, members of Nature and Youth Sweden made an appeal via the newspapers and radio to encourage 'the otherwise so passive city dweller to come out and make an active contribution to a more beautiful countryside'. They also sent an appeal, signed by Skåne's Province Governor Gösta Netzén, to 'everyone who might be interested in helping'. After the event, Fältbiologen reported that about 300 people had braved rain, wind, and cold to clean up the almost 20-km-long coastline between Landskrona and Barsebäck north of Malmö. The beaches had been 'veritable rubbish dumps' filled with 'plastic in all forms, bottles, petrol drums, etc'. The result

19 Håkan Agvald, 'Naturvårdare', FB, 4 (1965), pp. 22-23.

20 Olle, 'Gott nytt...', FB, 1 (1964), p. 2.

21 Hans-Georg Wallentinus, 'Den tysta våren redan på väg!', $F B, 3$ (1963), pp. 2-3; Hans-Georg Wallentinus, 'Samla kalla fakta', FB, 4 (1965), p. 24. 
was described as fantastic. In five hours and in abysmal weather conditions, 2,300 sacks had been filled and the coast cleared of some 700 tonnes of debris'.

Nature and Youth Sweden's cleaning operation was described as the biggest ever in Skåne, and it received significant attention in the press and broadcast media. This media coverage was in turn extensively reported in Fältbiologen, which devoted a double spread to press clippings and photographs of the event. The newspaper headlines described a 'Huge effort by nature people' and an 'army' of Nature and Youth Sweden members. The photographs showed children and young people collecting plastic and dragging bags of rubbish, soaked to the skin. ${ }^{22}$

This cleaning action in Skåne in the spring of 1966 was in many ways characteristic of the association at this time. The young people were shown to be capable, responsible, active, and enterprising. Through their knowledge of, and feelings for, nature, the association's members wanted to help society. They did not oppose any kind of establishment; on the contrary, they were happy to cooperate with, and be variously supported by, the adult world. Their activities and opinions harmonized well with those of the Swedish Society for Nature Conservation. Furthermore, the action shows that nature conservation in the mid-1960s was largely about enhancing the beauty of nature. It should be preserved so that it could be experienced. There was no social criticism, no political agenda, no imminent threat to humanity. But all this was about to change.

\section{Nascent environmental activism, 1967-1969}

At the beginning of 1967, Thomas Söderqvist became the new editor of Fältbiologen. His ambition was to make the magazine 'a provocative agency for debate', and he wanted every member of Nature and Youth Sweden to be a potential 'habitat warden'. Other members of the association's national council expressed similar views. There was talk of 'raising the standard of debate', providing 'ecological education', and turning members into 'nature-conservation propagandists'. ${ }^{23}$ These growing ambitions to recast the association's activities on the part of the national council coincided with the increasing momentum of the Swedish environmental debate.

22 Anders Rünow, 'Att städa en strand', FB, 2 (1966), pp. 7-11.

23 Anon., 'Sällskapet för inbördes beundran', FB, 1 (1967), p. 14. 
The definitive breakthrough occurred in the autumn of 1967. Scientific warning voices, for instance those of Hans Palmstierna and Svante Odén, were making a great impact. Fältbiologen's editorial staff intervened as well. One Saturday night, in early November, they went out into the Sergels Torg square in central Stockholm with tape recorders to ask young people what they felt and thought about nature conservation. The answers they received mainly focused on litter in nature. This angle was opposed by the editors. For them, nature conservation was about so much more than 'single-use glass and milk packaging'. It included the expansion of hydroelectric power on the Vindel River, biocides in agriculture, consumer responsibility, and the conflicts between environmental protection and economic growth. Consequently, the Fältbiologen editors were now critical of 'the SNF propaganda' against littering, claiming that it had given the public an overly narrow understanding of what environmental and nature conservation was all about. ${ }^{24}$

Outspoken criticism of the Swedish Society for Nature Conservation and Håll Sverige Rent was something new in Fältbiologen's columns. It marks the beginning of a process of growing politicization and a more independent involvement in the environmental debate. In the summer of 1968, Wolter Arnberg criticized the incumbent Social Democratic government. He asked what difference it made that the government had adopted an ambitious environmental policy programme when it continued to make environmentally destructive decisions in practice. Arnberg stressed that the government, in direct conflict with nature-conservation interests, had given the go-ahead for a new airport in the Sturup area in Skåne and for industrial exploitation of the Väröbacka area in Halland. 'The young generation', he wrote, 'has the right to demand not to have to bear the burden of a society that has to be given artificial respiration via a contaminated environment.' All exploitation must be conducted 'with a view to the future'. A 'hunger for prestige and short-term profit interests' should not be allowed to 'crush the very foundations of our generation'. ${ }^{25}$

In the same issue, Mats Segnestam drew a gloomy picture of Sweden's 'many and big' nature-conservation problems. He cited the use of biocides in agriculture, the sulphur dioxide in the air, the

24 Thomas Söderqvist, 'Miljövård på Sergels Torg en lördagskväll', FB, 5-6 (1967), pp. 22-24.

25 Wolter Arnberg, 'Vindelälven åter hotad', FB, 3 (1968), p. 2. 
mercury-poisoned lakes, gravel pits becoming depleted, and the difficulties in finding appropriate sites for 'nature-destroying facilities'. The situation demanded 'planning and long-term thinking' (italics in the original). However, he saw no sign of these. His list of conservation problems was only a small sample, he claimed, adding, '[a] complete list would be endless!'.

The extensive catalogue of problems was followed by a review of legislation, government bodies, nature-conservation organizations, and mass-media reporting. In these areas there were some hopeful signs. Segnestam emphasized that 'the average Swede' had probably 'begun to realize that nature conservation problems exist and perhaps suspect that they are serious'. The politicians had also realized 'that the general public has begun to wake up', and the political parties were therefore trying to 'surpass one another with ambitious environmental programmes'. If this could 'be put into practice, that would of course be excellent'. Segnestam hoped that the next generation would also have 'greater opportunities to absorb natureconservation thinking' from an early age. The school system's curricula were being updated, and over the past year 'a tidal wave of podium debates, lectures, conferences, courses, and study circles on nature conservation has swept over us'. The situation was serious, but enlightened public opinion was gaining strength. Segnestam concluded that 'Our nation [literally 'Mother Svea', an expression that serves as a national symbol in Sweden] must not and cannot turn a deaf ear any longer!'26

The articles by Arnberg and Segnestam were typical of the new socially critical position that Nature and Youth Sweden began to adopt in the late 1960s. The association's leading representatives increasingly turned against politicians and other people in power, including the National Environment Protection Board. Nature and Youth Sweden did welcome the founding of the Board, but quickly became a critical monitor of its activities. The existence of a national environmental policy establishment in Sweden as early as 1967 was very important to Nature and Youth Sweden and the emerging environmental movements in the country: it gave them a clear and legitimate opponent. This position enabled them to share in, and agree with, much of the general criticism of the establishment that

26 Mats Segnestam, 'Se - hur skönt landet ligger', FB, 3 (1968), pp. 13-15. For studies of national planning in the 1960s, see Katarina Nordström, Trängsel i välfärdsstaten: Expertis, politik och rumslig planering $i$ 1960- och 1970-talets Sverige (Uppsala: Studia Historica Upsaliensia, 2018). 
was gathering force during the late 1960s. As a result, Nature and Youth Sweden became part of the new political culture of the period. ${ }^{27}$

However, it took some time for Swedish society as a whole to discover that Nature and Youth Sweden had changed. As mentioned earlier, the Sergels Torg demonstration in March 1969 aroused surprise. But for Wolter Arnberg at the speaker's podium, criticism of society and the establishment was nothing new: he and others had been expressing these views in Fältbiologen's columns since 1967. The Sergels Torg protests were aimed at all forms of 'shortsighted planning' by Swedish authorities. In particular, Arnberg attacked 'Valfrid Paulsson and his National Environment Protection Board for their sickeningly watered-down nature-conservation policy'. He especially criticized the Board's putting the interests of the tourism industry before those of nature protection. 'Does the National Environment Protection Board want to build cabins in the national parks?' he demanded. ${ }^{28}$

Nature and Youth Sweden's demonstration on 16 March 1969 attracted attention not only from the press and broadcast media but also from the state-owned energy company Vattenfall, which was responsible for expanding hydroelectric power on the northern rivers. In conjunction with the Sergels Torg demonstration, the company's chief press and information officer made contact and asked representatives of Nature and Youth Sweden to come to Vattenfall's office the next day to discuss the issues. The proposal was accepted, and on the evening of 17 March there was a panel debate led by Eskil Block, a scholar specializing in future studies. Nature and Youth Sweden's representatives Wolter Arnberg and Lars-Erik Liljelund were pitted against Vattenfall's director-general Erik Grafström and civil engineer Väinö Wanhainen. The four-hour debate was recorded by Radio Sweden, which broadcast a feature about it on the late TV news. ${ }^{29}$

A week later, members of Nature and Youth Sweden, led by its chair, Wolter Arnberg, visited Minister for Agriculture Ingemund Bengtsson. They handed him a letter and expressed their views. In

27 Salomon, Rebeller $i$ takt med tiden; Östberg, 1968 - när allting var $i$ rörelse; Östberg and Andersson, Sveriges historia; Jørgensen, Transformation and Crises; Berggren, 68.

28 Wolter Arnberg, 'Tal framfört på Sergels Torg den 16.31969 vid Fältbiologernas demonstration mot vattenkraftutbyggnaden i fjällen', FB, 3 (1969), p. 5.

29 Erik Isakson, 'Sluta reglera våra älvar', FB, 3 (1969), pp. 5-6. 
Fältbiologen Erik Isakson reported that the minister 'listened kindly, but had some trouble understanding our pessimistic view of the future and of environmental protection'. Bengtsson wanted the young people to be optimistic about the future. He emphasized that much had already been done in Sweden and pointed out that no other country in the world had introduced such stringent restrictions on environmental destruction. Isakson was not convinced. He was certain that the future would prove the leading Social Democratic politicians wrong. The situation, he said, was far more serious than they imagined. ${ }^{30}$

Nature and Youth Sweden's increasingly fierce criticism of the establishment had one exception: the scientific research community, with which the association had always had close ties. In the late 1960s several of its leading members, including Thomas Söderqvist and Wolter Arnberg, had been university students with research ambitions. The association was especially favourably disposed towards the new environmental debaters. Both Hans Palmstierna and Nils-Erik Landell were given space to write for Fältbiologen. The fact that Palmstierna was an active Social Democrat was not a disadvantage. He was a scientific voice whom the nascent environmental activists wholeheartedly supported. ${ }^{31}$

Even so, this growing engagement with environmental policy did not mean that field studies and outdoor life were given less priority. These traditional activities continued to be central, and Fältbiologen regularly published reports and informative texts along those lines. In 1968, for example, Erik Isakson wrote an in-depth guide to the equipment that a Nature and Youth Sweden member would need in order to survive in Sweden's mountain areas. It was vital to know about everything from tents and backpacks to clothes and provisions. ${ }^{32}$ Later he shared his experiences of various kayaks and types of ski equipment. ${ }^{33}$

In 1969, Erik Isakson became editor of Fältbiologen. In his first editorial, he described his 'happy youth' when he had spotted 350 species of birds. Now, though, he had 'discovered that there are other things than bird species in nature', and that 'Stockholm is

30 Ibid., p. 6.

31 Hans Palmstierna, 'Undvik vägen utan återvändo', FB, 4 (1968), pp. 3-5; Nils-Erik Landell, 'Hur ska vi ändra framtiden', FB, 6 (1969), pp. 4-5.

32 Erik Isakson, 'Skogsliv till fjälls', FB, 2 (1968), pp. 3-6.

33 Erik Isakson, 'Kanoter', FB, 5 (1969), pp. 11-13; Erik Isakson, 'Skidor och bindningar', FB, 6 (1969), p. 16. 
dirty and destructive to humans'. He criticized the 'human spirit of development', stressing that all scientific and technological advances brought 'unsuspected disadvantages'. Today's situation could perhaps be mastered 'if we did more than today's petty efforts'. At the same time, though, 'new so-called advances were constantly taking place, which in their turn had unsuspected effects'. The new editor advised his readers to go and visit the mountains before they were destroyed. ${ }^{34}$

Isakson's criticism of civilization ran like a central thread through Fältbiologen during 1969, and his own texts came to revolve more and more around 'Greenland'. For him, it became a symbol of 'the free life far from the devastating effects of modern technology'. Nature and Youth Sweden's debates with Vattenfall and Valfrid Paulsson in the spring of 1969 made him 'rather sad'. In his view, 'the ruling politicians and the sausage-stuffed experts' were unyielding in their belief 'in the redeeming effect of technology for humanity'. Continued debate was pointless and had about the same effect as stamp collecting. Isakson hence urged his readers to strive to be independent of technology and to turn their backs on modern society. ${ }^{35}$

Erik Isakson was not alone in raising his voice in 1969. Under his editorship, critical debate and social criticism were given more and more space in Fältbiologen. Writers began to depict historical developments in sombre colours. Kristoffer Andersson described how industries had 'popped out of the earth like poisonous mushrooms' and how environmental destruction was now coiling its way 'like a hungry Midgard serpent around the entire globe'. ${ }^{36}$ Ulf Rooth argued that Nature and Youth Sweden had to keep up with the times and update its goals. Field studies and peer education were no longer sufficient. The association's task should be 'to spread information about environmental destruction to the people, and to present their and our views to the politicians'. ${ }^{37}$

Lifestyle issues also began to be discussed at this time. Marianne Reini maintained that it was important for members of Nature and Youth Sweden to practise what they preached. 'How can we criticize

34 Erik Isakson, 'Gifterna åt människan', $F B, 1$ (1969), p. 2.

35 Erik Isakson, 'Variation nummer fyra', FB, 3 (1969), pp. 2-3. 'Sausage-stuffed' is a literal translation of a Swedish expression, signifying massive soulless cramming.

36 Kristoffer Andersson, '?’, FB, 2 (1969), p. 2.

37 Ulf Rooth, 'Naturen, Fältbiologerna och Samhället', FB, 6 (1969), pp. 2-3. 
environmental destruction as long as we ourselves use the products that are being manufactured?' she demanded. ${ }^{38}$

The magazine's former editor, Thomas Söderqvist, said that he had moved out to a smallholding in the country - an act he wanted to 'propagandize for'. ${ }^{39}$ As usual, Erik Isakson's was the most radical voice. He talked about moving to Greenland and also of 'mustering a guerrilla army and resorting to violence'. ${ }^{40}$ Much had changed since the good-natured cleaning action in Skåne in the spring of 1966.

\section{Radical social critics, 1970-1972}

Nature and Youth Sweden began the 1970s by demonstrating on the streets of Norrköping (a city some $160 \mathrm{~km}$ south-west of Stockholm, with a population of about 140,000) and adopting the association's first political programme. That happened at the annual meeting in early January when more than a hundred members gathered to socialize, go on excursions, make placards, and attain shared 'doctrines and values'. The new programme announced that we humans were 'obliged to preserve our limited natural environment for the sake of future generations' and that the population explosion had 'developed into a catastrophe'. It also asserted that the Swedish authorities either did not realize the seriousness of the situation or failed to accept the 'consequences of their realization'. The measures that the politicians had implemented and were planning were dismissed as 'completely insufficient'. ${ }^{41}$

The overall goal of Nature and Youth Sweden's political programme was that 'our civilization' should not 'make a rich and varied biological life on Earth impossible in the future'. To ensure this would not happen, the association would 'spread knowledge and awareness of nature-conservation issues', provoke debate, demonstrate, write letters, and carry out direct actions. Members should 'assert their views according to their conviction', whether

38 Marianne Reini, 'Inlägg i debatten om Fältbiologerna', FB, 6 (1969), p. 3.

39 Thomas Söderqvist, 'Tankar från torpet', FB, 4 (1969), p. 23.

40 Erik Isakson, '?', FB, 2 (1969), p. 2; Erik Isakson, 'Detta nummer', FB, 6 (1969), p. 2.

41 Anon., 'Program för Fältbiologernas naturvårdsverksamhet antaget av årsmötet 1970', FB, 1 (1970), p. 3; Rolf Jacobsson, ‘Årsmötet 1970', FB, 1 (1970), pp. 20-21. 
or not they agreed with the views of any political party or gave positive or negative publicity to the association. ${ }^{42}$

The 1970 annual meeting developed into a manifestation of the transformation that had taken place in Nature and Youth Sweden. Rolf Jacobsson proudly described in Fältbiologen how 'flaming torches lit up our placards', which 'shouted out terrifying and accusatory truths to the sceptical world around us'. It was reported that the local press had portrayed the demonstration as 'a powerful indictment of society'. ${ }^{43}$ In the same issue, Erik Isakson pointed out that 'the material standard of living must be lowered' if 'life on Earth is to continue'. ${ }^{44}$

The growing political involvement within Nature and Youth Sweden had a bias towards the political left. The clearest example of this was Thomas Söderqvist. In the autumn of 1970, he encouraged all members of the association to contact left-wing political action groups. For him, the environmental crisis was interwoven with a profound social crisis of global proportions. It was therefore pointless to look for technological solutions to the environmental problems. A radical transformation of society was required. 'The real enemy', he argued, 'is the inhumanity that emerges in the industrialized affluent societies.' This enemy could be labelled 'capitalism, bureaucracy, imperialism, or whatever you want'. The basic problem was the same: the blind pursuit of material growth. This could only be attacked politically. For that reason, he believed that members of Nature and Youth Sweden should ally with the New Left. ${ }^{45}$

Söderqvist's contribution to the debate did not go unchallenged. Outraged members of the association contacted the editorial department and questioned 'the validity of conducting political propaganda in the magazine'. ${ }^{46}$ As editor, Erik Isakson stressed that Söderqvist's post was not written 'in the association's name'. ${ }^{47}$ At the same time he afforded space to a text by Wolter Arnberg, chair of the association, about its new political programme. Arnberg summarized and commented on the 'doctrines and values' adopted at the annual meeting.

42 Anon., 'Program för Fältbiologernas naturvårdsverksamhet antaget av årsmötet 1970 ', p. 3.

43 Jacobsson, ‘Årsmötet 1970’, p. 21.

44 Erik Isakson, 'Förbjud snöskotrarna', FB, 1 (1970), p. 3.

45 Thomas Söderqvist, 'Politisera miljövårdsdebatten!', FB, 3-4 (1970), pp. 30-31.

46 Anders Fridell, 'Politisk propaganda', FB, 5 (1970), p. 29.

47 Erik Isakson, 'Från när och fjärran', FB, 5 (1970), p. 25. 
He stressed that 'environmental protection is politics' and that the association's task was 'to try to increase your knowledge about your surroundings and to create a pressure group for the care of our environment'. Nature and Youth Sweden would be an active voice in the environmental debate and one that expressed political views based on 'biological facts'. ${ }^{48}$

Nevertheless, opinions were divided as to how the association should proceed. Torbjörn Kronestedt felt that Söderqvist was advocating an overly idealistic position. To bring about real change, people needed to be realistic and willing to cooperate both with politicians and with the scientific research community. 'A general mood of dissatisfaction with a global set of problems produces little result', he declared. ${ }^{49}$ Söderqvist replied that Kronestedt was being deceived. 'The powerful authorities and the powerful business community have long tried to convince us that society can only function in this way.' The school system and mass media had been indoctrinating us all 'since we were toddlers'. The Swedish welfare state was built on 'the doctrine of growth'. This approach was no longer defensible because 'increased, uncontrolled economic growth poses the greatest threat to positive ecological interaction'. Capitalism was the problem according to Söderqvist, who added that only the left-wing groups shared this insight and offered alternatives. ${ }^{50}$

As we have seen, Fältbiologen became a forum for internal debate about political ideology in the early 1970s. Conceptually, there was also a shift in emphasis from 'nature conservation' to 'environmental protection'. The changes coincided with the association's new valorization of knowledge about how society functioned. Environmental protection was considered to be fundamentally a social and political issue. It was therefore no longer sufficient for members of Nature and Youth Sweden to possess in-depth knowledge about bird species and outdoor life. The magazine's editorials recommended a number of books, published by the state-owned Allmänna förlaget [General Publishing], which could be read in study groups. The books reflected 'society's view of the environmental-protection problem and how it should be solved', which was important for members to know before they contacted various authorities. ${ }^{51}$

48 Wolter Arnberg, 'Fältbiologerna och deras politik', FB, 5 (1970), pp. 25-26.

49 Torbjörn Kronestedt, 'Först vettig “miljövårds”-debatt här hemma', FB, 5 (1970), pp. 26-27.

50 Thomas Söderqvist, 'Död åt vinstintressena', FB, 5 (1970), p. 28.

51 Lars-Erik Liljelund, 'Vad gör samhället för vår miljö’, FB, 4 (1971), p. 78. 
The association's social criticism was primarily aimed at the Social Democratic establishment and in particular at the directorgeneral of the National Environment Protection Board, Valfrid Paulsson, and the minister for agriculture, Ingemund Bengtsson. Nature and Youth Sweden regarded the two men as opportunistic defenders of modern industrial society. A satirical series published in 1971 described Paulsson as 'the little watchman of all nature'. He saw all the environmental destruction going on and reacted with lightning speed. But not by stopping the transgressions and punishing the offenders. Instead, he made sure to track down all the 'illegal destroyers of the environment' and give them a permit. $^{52}$

Lars-Erik Liljelund argued that the National Environment Protection Board was not very 'non-profit-focused'. He said that the Board kept making decisions that went against environmentalprotection interests. Liljelund found it remarkable that Paulsson 'almost never publicly criticizes the environmentally hazardous activities of various companies and municipalities'. What he did do, according to Liljelund, was to repeatedly make 'rancorous jabs at the large group of people who feel powerless and concerned about the future and the environment we will have'. Who were Paulsson's true opponents, Liljelund asked - the actors who were destroying the environment or the ones that were trying to protect it? ?3 $^{53}$

Nature and Youth Sweden also expressed its political commitment in the form of direct actions. These were designed to provoke media commotion about various environmental protection problems, with the aim of influencing public opinion and promoting change. In the wake of successful actions, Fältbiologen would publish reports and press clippings. The stated purpose was to inspire imitation and to spread knowledge within the association about how environmental-protection actions could best be carried out. It is noteworthy that the association was employing these deliberate media strategies at such an early stage. Over time, these methods became characteristic of the international environmental movement, not least through Greenpeace, which was formed in Canada in $1971 . .^{54}$

52 Lars Olsson, 'VIP=Very Important Paulsson', FB, 1 (1971), p. 30. Cf. Per Jadéus, 'Oberättigad kritik?', FB, 2 (1972), p. 47 (a humorous sketch of Valfrid Paulsson).

53 Lars-Erik Liljelund, 'Hej', FB, 5-6 (1971), pp. 82-83.

54 Zelko, Make it a Green Peace! 
In April that same year, the Nature and Youth Sweden club in the small town of Mariestad carried out a direct action over rubbish, with the intention of raising awareness of local waste-management problems. The club's members acted as investigative journalists, and Bo Landin proudly reported how they had tricked those responsible into exposing bad practices. Among other things, the members had gone to the local landfill site and pretended to be 'pupils interested in photography who perceived something beautiful in the rubbish'. On another occasion, they had pretended to be one 'Mr Gustafsson' who wanted to scrap a car. They had then found out that the private company operating the landfill had 'a contract with an old fellow in the forest'. So here was one reason why there were so many scrap cars in the countryside!

The club's revelation of the abuses was carefully orchestrated. Its members secretly prepared an exhibition at the local bank branch, wrote a letter to the local health authority, and ensured that the local press was on standby. A relevant circumstance here is that two of the club members worked for the local newspaper, Tidning för Skaraborgs län. This allowed them to steer the press coverage and the subsequent debate. Landin reported that the revelation of the mismanagement of the rubbish tip had led to 'chaos and consternation' in Mariestad. This was followed by new headlines about the scandal, complaints being filed to the police, and - soon after - actual changes in how the waste was managed. Nature and Youth Sweden itself considered the end result of the action to be 'sensational'. ${ }^{55}$

In the spring of 1972, Nature and Youth Sweden joined forces with Miljögruppernas riksförbund (MIGRI) [the National Association of Environmental Groups] and Jordens Vänner [a co-founder of the Swedish branch of the international organization Friends of the Earth] to carry out a nationwide campaign against single-use packaging. The week-long endeavour included distributing flyers, holding demonstrations, and collecting signatures. The so-called 'packaging action' attracted the most attention. This involved members of Nature and Youth Sweden going out into the countryside throughout Sweden and collecting discarded single-use packages. These were then wrapped up and posted to the Swedish government, the Riksdag, the National Environment Protection Board, and the leading Swedish packaging manufacturer PLM. Dagens Nyheter reported that 160,000 beer cans had been sent by post. Valfrid Paulsson condemned the action

55 Bo Landin, 'Sopaktion i Mariestad', FB, 5-6 (1971), pp. 109-113. 
as 'completely insane', adding that 'we environmentalists must beware of appearing as foolish romantics'. ${ }^{56}$

Of course, Nature and Youth Sweden took a different view of the matter, regarding the campaign as a 'complete triumph'. About a hundred of the association's clubs, plus about fifty other environmental-conservation groups, were reported to have taken part in it. In addition, 70,000 signatures were reportedly collected against 'the single-use hysteria'. Nature and Youth Sweden felt that the association had imparted 'full speed to the debate over the waste of raw materials'. It added that PLM had been forced to admit that it was driven solely by profit motives and did not care about the environmental consequences of its activities. ${ }^{57}$

Nature and Youth Sweden's radical criticism of the establishment was also directed at the upcoming UN conference in Stockholm. Lars-Erik Liljelund joked that the environmental-protection conference was a 'weapon of total annihilation against the global environmental destruction'. He objected to the exclusion of the general public, not least 'rebellious elements' in it. The conference only existed so that 'the real decision-makers' could meet and discuss 'the problems they themselves have caused'. ${ }^{58}$ Christina Skarpe argued that no improvements came from adopting declarations and resolutions. She felt that the main value of the conference was 'the publicity it will give to environmental protection'. She also regretted that the conference focused on 'finding ways to combat the symptoms of environmental problems, rather than preventing their emergence'. ${ }^{59}$

Nature and Youth Sweden was indirectly represented at the Stockholm Conference by the International Youth Federation for the Study and Conservation of Nature (IYF, founded in 1956). In the summer of 1971, the above-mentioned Christina Skarpe and Bo Landin had participated in the organization's conference in Canada. Their experience from that event was that international environmental protection work was complex and difficult. Cooperation between participants from the industrialized and developing countries was particularly tricky. In his report, Landin wrote that it boded ill for the future that the latter's representatives were not interested 'in hearing how we are now trying to solve problems which they

56 Christina Kellberg, 'Paulsson rasar över ölburkarna: "Ansvarslöst av fältbiologerna”', DN, 18 April 1972.

57 Bo Landin, 'Fältbiologerna till attack!', FB, 3 (1972), pp. 62-64.

58 Lars-Erik Liljelund, 'Hej', FB, 4 (1971), p. 4.

59 Christina Skarpe, 'Vad händer i Stockholm?', FB, 2 (1972), pp. 35-36. 
don't have yet and learning from us'. Instead, the developing countries' representatives were more eager to assert 'their position in the world and their independence'. ${ }^{60}$ The lecturing attitude expressed in Landin's report is likely to have been one of the reasons for the difficulties in cooperation.

Even so, members of Nature and Youth Sweden who wanted to be directly involved in the Stockholm Conference and in arrangements connected with it did have some opportunities. Christina Skarpe explained that two open meeting-places would be set up: 'Environment Forum' and 'Folkets Forum' [The People's Forum]. The former was organized by the UN Association of Sweden and the National Council of Swedish Youth (SUL), while the latter brought together newly founded environmental groups such as Jordens Vänner [Friends of the Earth], Dai Dong, and Powwow. ${ }^{61}$ Nature and Youth Sweden did not assume any official position regarding the two forums, but for the association's radical elements the choice was not difficult. Folkets Forum offered a meeting place for environmental and establishment criticism with ties to the New Left. ${ }^{62}$

\section{Nature and Youth Sweden and the environmental movements in Sweden}

The transformation of Nature and Youth Sweden is an important part of the history of the Swedish environmental movements. What makes the association especially interesting is that it spans and connects several different lines of development. Nature and Youth Sweden was founded within an older nature-conservation tradition and was, as we have seen, firmly anchored in that tradition until the autumn of 1967. After that, a gradual politicization occurred, especially at the leadership level in Stockholm. In the early 1970s, more and more members of the association became environmental activists. The members' young age made knowledge about the global environmental crisis a particularly urgent matter for them. Environmental destruction and unfettered economic growth posed a direct threat: what was at stake was their own future.

60 Bo Landin, 'IYF', FB, 4 (1971), pp. 71-74.

61 Christina Skarpe, '... och var kommer vi in i bilden?', FB, 2 (1972), pp. 37-38.

62 Lars Gogman, 'Rödgrönt samarbete med förhinder', Arbetarhistoria 142.2 (2012), p. 48. 
Even after this radicalization, however, older ideals rooted in nature-orientated Romanticism were very much alive within the association. This is how its magazine's editor, Roger Olsson, described what was behind his own involvement in the environmental debate in the summer of 1972: 'For me, it is the feeling for nature', he wrote, 'a feeling created by all the experiences of happiness nature has given me.' He hoped and believed that most members of Nature and Youth Sweden had the same motivation for their actions. 'Because it is a good foundation. One knows and feels that one is fighting for something incredibly valuable, something that is far more necessary than everything else.' In his view, the association's most important task was hence always to arouse feelings for nature in its members. If they also had time to hand out leaflets, scold Vattenfall, and send beer cans to the minister for agriculture, that was a good thing. But it was not as important as actually experiencing and studying nature. A field biologist's boots should be kept muddy. ${ }^{63}$

Roger Olsson's comments reveal the tension between an apolitical interest in nature and radical environmental activism. At the beginning of the 1970s, Nature and Youth Sweden encompassed both. The relative importance of different ideals and practices was not obvious. In this respect, too, there are interesting differences between Nature and Youth Sweden and its parent organization, the Swedish Society for Nature Conservation (SNF). The latter also underwent a revolutionary change in the years around 1970, as voices critical of civilization and economic growth became ever stronger. ${ }^{64}$ Nevertheless, SNF continued to have close ties with established institutions in Swedish society. The adult members' commitment to environmental protection and nature conservation was not manifested in demonstrations and direct actions, and the political culture of the New Left did not have the same appeal to them.

Other environmental organizations did have a more obvious extra-parliamentary left-wing profile. They notably included the environmental groups and residents' associations in Sweden's major cities, who opposed concrete transformations of the urban environment. Among these, Göteborgs miljögrupp [Gothenburg's Environmental Group] and Alternativ stad [Alternative City] in Stockholm are especially well known. The latter was strongly involved in the so-called 'Battle of the Elms' in the spring of 1971, when protesters sought to prevent the felling of thirteen elm trees in the

63 Roger Olsson, 'Håll stövlarna leriga!', FB, 4 (1972), p. 74.

64 Anshelm, Det vilda, det vackra och det ekologiskt hållbara, pp. 60-72. 
Kungsträdgården park in central Stockholm. (They succeeded; the elms are still standing.) The action received much media attention, and, like Nature and Youth Sweden's actions, it expressed sharp criticism against the establishment. ${ }^{65}$ The residents'-association movement was loosely organized. It played a part both in the design of the physical urban environment and in the creation of a sense of community among people in a neighbourhood. The focus tended to be on local issues, such as opposing demolition or new construction. ${ }^{66}$ For these organizations, environmental toxins, industrial exploitation of the wilderness, and global survival problems were not such key issues as they were for Nature and Youth Sweden or for the Swedish Society for Nature Conservation.

Environmental commitment in Sweden was also channelled through the established political parties, especially their youth wings. Most important in this context was the youth wing of the agrarian nonsocialist centre party, Youth League of the Centre (CUF) [now Centre Party Youth]. CUF was involved in urban transformation, rural depopulation, and issues to do with global resources and justice. Its political vision was a decentralized society in which public authorities and technocratic experts had less say. Democracy should be built around strong local communities, and CUF therefore advocated an active regional and localization policy. Like Nature and Youth Sweden, CUF took the global environmental crisis very seriously and warned against blind trust in economic growth and technological progress. For obvious reasons, however, there was not the same radical critique of the capitalist system within CUF. It also distanced itself to some extent from the New Left's culture of political action. ${ }^{67}$

In the early 1970s, a number of new environmental organizations were formed in Sweden. They included Jordens Vänner [Friends of the Earth] and the national association of environmental groups,

65 Daniel Halldén, Demokratin utmanas: Almstriden och det politiska etablissemanget (Stockholm: Department of Political Science, University of Stockholm, 2005).

66 Ulf Stahre, Den alternativa staden: Stockholms stadsomvandling och byalagsrörelsen (Stockholm: Stockholmia, 1999). For studies of the Swedish alternative movement see Kristoffer Ekberg, Mellan flykt och förändring: Utopiskt platsskapande i 1970-talets alternativa miljö (Lund: Department of History, University of Lund, 2016).

67 Carl Holmberg, Längtan till landet: Civilisationskritik och framtidsvisioner i 1970-talets regionalpolitiska debatt (Gothenburg: Department of History, University of Gothenburg, 1998). 
Miljögruppernas riksförbund (MIGRI). ${ }^{68}$ The latter was led by Björn Gillberg, a young researcher into heredity who was beginning to make a name for himself in the autumn of 1969 with the debate paperback Hotade släktled [Threatened Generational Descent]. Gillberg especially focused on environmental toxins. He argued that too much attention was being given to direct damage by toxins whereas their long-term effects on genetic material, and thus on future generations, were being ignored. ${ }^{69}$ The following year he went on the offensive against the detergent industry. Gillberg warned that laundry detergents contained potentially carcinogenic substances and that the authorities were defending the interests of big business. He made the attack in and through Dagens Nybeter ${ }^{70}$

Gillberg experienced his big media breakthrough on 12 October 1971 with the prime-time broadcasting by Swedish TV2's environmental department of the programme 'Han kan bara inte halla käften' [He just can't shut up]. It portrayed Gillberg as a young, angry environmental debater who was not afraid to speak truth to power. Particularly striking was the fact that he washed his shirts with a coffee whitener called Prädd. The product quickly vanished from the market and Gillberg became, in the words of the historian of science and technology Per Lundin, 'a media darling'.

Lundin has analysed Gillberg's actions in the environmental debate of the early 1970s and their consequences. He points out that at the time of his breakthrough, Gillberg was employed as a project researcher at the Swedish University of Agricultural Sciences (SLU) outside Uppsala. He therefore possessed the scientific legitimacy necessary for him to be able to act as an expert in the media. Gillberg proved to be skilled at handling media logic. He made dramatic moves, issued blunt messages, and used instructive examples as well as simple language. His cocksure style led to attention and headlines but encountered a sceptical attitude in the research community.

68 Peter Larsson, 'Miljörörelsen', in Mats Friberg and Johan Galtung (eds), Rörelserna (Stockholm: Akademilitteratur, 1984), pp. 249-263; Magnus Boström, Miljörörelsens mångfald (Lund: Arkiv, 2001).

69 Björn O. Gillberg, Hotade släktled: Genetisk bakgrund till några viktiga miljövårdsproblem (Stockholm: Natur \& kultur, 1969); Björn O. Gillberg, 'Hotet mot arvsmassan', DN, 20 November 1969.

70 Björn O. Gillberg, 'Naturvårdsverket spelar tvättmedelsföretagen i händerna', DN, 5 June 1970; Erik Brandt, 'Kemikontoret om NTA-stoppet: Nej, vi gick inte företagens ärenden', DN, 13 June 1970; Björn O. Gillberg, 'Visa byken om tvättmedel offentligt', DN, 3 July 1970; Barbro Josephson, 'Optiskt vitt - den nya faran?', DN, 24 August 1970. 
Gillberg's media success hence undermined his scientific legitimacy, which made his media position untenable in the long term. In order to deal with the situation, he sought to strengthen and consolidate his position within MIGRI. The movement raised funds for his research and set up the Miljöcentrum [Environmental Centre] foundation. In 1972, the foundation began publishing its own periodical Miljö o framtid [Environment and future]. ${ }^{71}$

At the time of the Stockholm Conference in 1972, Björn Gillberg's position in the media and in the Swedish environmental movement was still strong. Scientifically, however, he was marginalized. The big packaging action carried out by Nature and Youth Sweden and MIGRI against PLM was not something that was highly valued in the world of research. The many controversies surrounding Gillberg were typical of him as an environmental debater. Seen from a slightly longer time perspective, however, they were also typical of the Swedish environmental debate in the early 1970s. In this respect, an important dividing line runs between this debate and that of the late 1960s, especially of the breakthrough stage. In the autumn of 1967, the social circulation of knowledge in Sweden was characterized by relative consensus. At that time, it was appreciated that an actor like Hans Palmstierna built bridges between the worlds of science, media, and politics. Nor did the interest in environmental issues have any obvious political colouring at that point.

In the early 1970s, the situation was different. The political culture was transforming, and there were conflicts regarding the nature and status of factual knowledge. This chapter has shown how young environmental activists turned against the established society. But the cracks existed in the adult world as well. As environmental issues became politicized, the lines of conflict between various interest groups in society became more apparent. This was also true with regard to the sciences, and the ensuing chapter presents two open conflicts which attracted much attention in Sweden in the early 1970s.

71 Per Lundin, “Han kan bara inte hålla käften”: Björn Gillberg, lantbruksvetenskapernas medialisering och 1970-talets miljödebatt' (unpublished manuscript). 